\title{
Testing methods for exhaust toxic emissions from vehicles in Poland
}

\author{
J. Merkisz ${ }^{1} \&$ W. Gis ${ }^{2}$ \\ ${ }^{1}$ Institute of Combustion Engines and Transport, \\ Poznań University of Technology, Poland \\ ${ }^{2}$ Motor Transport Institute, Warsaw, Poland
}

\begin{abstract}
This paper presents regulations and testing methods of exhaust emissions of toxic components from vehicles particularly with respect to testing methods under real traffic conditions. The testing methods in Poland refer to American methodology, which is the most advanced in terms of technology.

The paper presents comparative tests of the exhaust emission of toxic components $\left(\mathrm{CO}, \mathrm{CO}_{2}, \mathrm{THC}, \mathrm{NO}_{\mathrm{x}}\right)$ from engines on a test bed with the use of modern testing apparatus for the examinations of emissions under real traffic conditions (on-vehicle testing).
\end{abstract}

Keywords: real traffic conditions, emissions.

\section{European regulations and testing methods}

In Europe, legal regulations determine emission values of the exhaust toxic components: carbon monoxide $\mathrm{CO}$, unburned hydrocarbons $\mathrm{HC}$ and hydrocarbons released through evaporation (VOC-Volatile Organic Compound), nitrogen oxides $\mathrm{NO}_{\mathrm{x}}$, and also PM released with the exhaust gases. The emission of harmful substances from vehicles is tested on the chassis dynamometer and sole combustion engines on engine test beds. Due to the high cost of the test equipment and complexity of the tests, it is possible to use one measuring system for both types of testing. Basic EU Directives and UN-ECE Regulations contain rules on conducting the aforementioned tests together with the regulations for the measuring equipment.

In the beginning of 2005 in Europe a new set of regulations was introduced, concerning emissions from the M1 and N1 category vehicles. They are called Euro IV and Euro V. The test was done using the NEDC test (Fig. 1) [1-3]. 
New regulations introduced not only more stringent requirements for the vehicles they refer to, but also for the research laboratories as far as the equipment level and testing methods are concerned. Compliance with these requirements is verified during:

a. type approval of vehicles (tab. 1),

b. conformity of production (COP),

c. in-service conformity.

Table 1: $\quad$ Procedures for type approval in Europe [1].

\begin{tabular}{|c|c|c|}
\hline Type approval test & $\begin{array}{l}\text { Positive-ignition } \\
\text { engines }\end{array}$ & $\begin{array}{l}\text { Compression-ignition } \\
\text { engines }\end{array}$ \\
\hline $\begin{array}{l}\text { I: NEDC - simulating the average } \\
\text { exhaust emissions during cold } \\
\text { start (Fig. 4) }\end{array}$ & \multicolumn{2}{|c|}{ According to EURO standards } \\
\hline $\begin{array}{l}\text { II: carbon monoxide emission test } \\
\text { at idling }\end{array}$ & $\left|\begin{array}{lr}0.5 \% \text { CO (content } \\
\text { by volume) at } \\
\text { normal idling }\end{array}\right|$ & $\begin{array}{l}\text { smokiness of exhaust } \\
\text { gases during free } \\
\text { acceleration: } 2.5 \mathrm{~m}^{-1}- \\
\text { naturally aspirated diesel } \\
\text { engines } 3.0 \mathrm{~m}^{-1}-\text { turbo- } \\
\text { charged diesel engines }\end{array}$ \\
\hline \begin{tabular}{|lrrr} 
III: verifying & emissions & of \\
crankcase gases & & \\
\end{tabular} & zero & - \\
\hline $\begin{array}{l}\text { IV: determination of evaporative } \\
\text { emissions }\end{array}$ & $\begin{array}{l}\text { evaporative test } \\
2 \mathrm{~g} \mathrm{HC}\end{array}$ & - \\
\hline $\begin{array}{l}\mathrm{V}: \text { durability of aftertreatment } \\
\text { devices }\end{array}$ & \multicolumn{2}{|l|}{$100000 \mathrm{~km} / 5$ years } \\
\hline VI: test UDC in $-7^{\circ} \mathrm{C}$ & $\begin{array}{l}\mathrm{CO}=15, \mathrm{HC}= \\
1.8 \mathrm{~g} / \mathrm{km}\end{array}$ & - \\
\hline VII: on-board diagnostic & from $2001 \mathrm{r}$. & from $2003 \mathrm{r}$. \\
\hline
\end{tabular}

According to the 96/96/EC Directive relating to roadworthiness tests, admissible values of $\mathrm{CO}$ for low emission vehicles fitted with PI engines, at idle speed, should be the same as stated by the manufacturer. Only when these values are not available, the fixed values set forth in the Directive, equaling $0.3 \%$ vol. $\mathrm{CO}$ at high idle speed, are obligatory.

The value of the absorption coefficient can be compared with the emission limits of the PM, and this was done for the passenger cars with the CI engines for the successive Euro standards. Limits for the absorption coefficient are as follows: Euro I-Euro III standards $-3.0 \mathrm{~m}^{-1}$, Euro IV $-1.5 \mathrm{~m}^{-1}$ and for Euro V the expected limit is $0.05 \mathrm{~m}^{-1}$ [2].

In the amendment 05 there is a new type VI test introduced concerning the emissions of the toxic components in the ambient temperature of $-7^{\circ} \mathrm{C}$ following a cold engine start. This test is applicable only to the M1 category vehicles and a part of the N1 category, fitted with PI engines. In this case the emission of CO and $\mathrm{HC}$ gets restricted. 


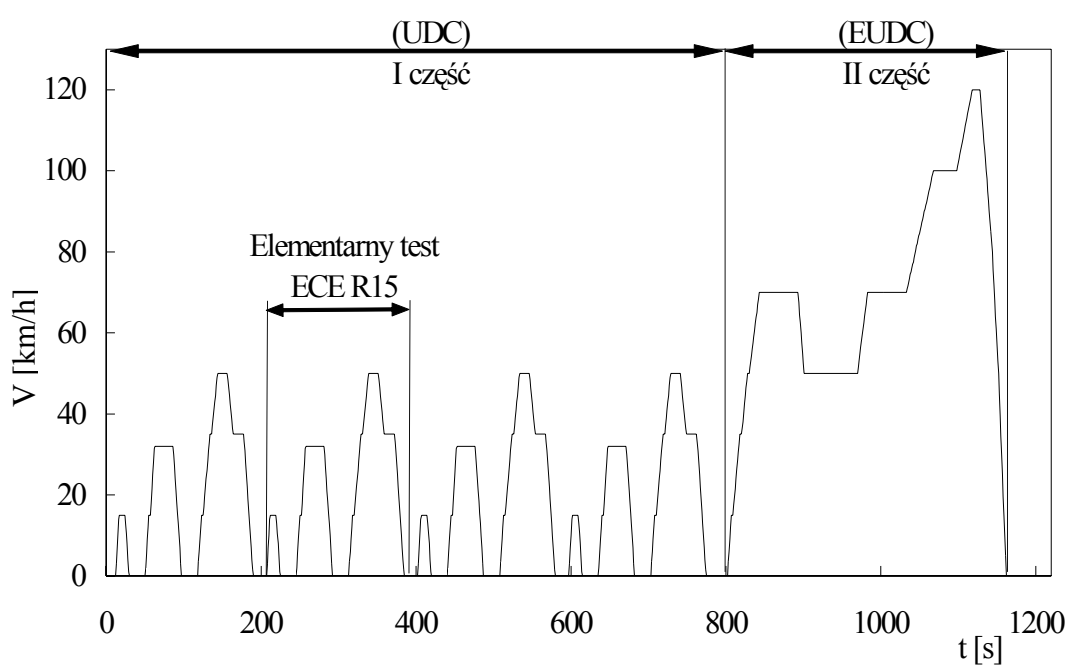

Figure 1: Operating cycle for NEDC (UDC + EUDC) test [2].

Admissible values are however relatively high and meeting these requirements will not cause significant technical difficulties. For the investigation in the type VI test, it is necessary to use low temperature chamber equipped with a chassis dynamometer and adequate exhaust collection system. The requirements are obligatory while conducting this type of tests for the remaining N1 category vehicles (from 1.01 .2003 for class $\mathrm{I}-\mathrm{CO}=15 \mathrm{~g} / \mathrm{km}, \mathrm{HC}$ $=1.8 \mathrm{~g} / \mathrm{km}$, for class II $-\mathrm{CO}=24 \mathrm{~g} / \mathrm{km}, \mathrm{HC}=2.7 \mathrm{~g} / \mathrm{km}$, for class III $-\mathrm{CO}=30$ $\mathrm{g} / \mathrm{km}, \mathrm{HC}=3.2 \mathrm{~g} / \mathrm{km})$.

The requirements concerning the OBD system:

- The EOBD system, compulsory for CI engines, was introduced on 1.01.2005 - for the M1 category passenger cars and the N1 category, class I trucks, and from 1.01.2006 - for trucks of the N1 category, class II and III. The serviceability period of all the elements having influence on the exhaust emission after $100000 \mathrm{~km}$ has been extended as well.

\section{American regulations and testing methods}

\subsection{Federal and Californian requirements}

In the US the investigations are carried out using the FTP75 test (Fig. 2). Main emphasis is put on the emission of HC, for which the LEV and ULEV standards are only $30 \%$ and $16 \%$ respectively in the federal standards from 1994 and Californian standards from 1993. Hydrocarbons or, more precisely, - nonmethane organic gases (NMOG) and $\mathrm{NO}_{\mathrm{x}}$ are important pollutants in the state of California, because both of them cause the formation of the ozone layer, which generates smog. 
CARB LEV/ULEV legislation causes great difficulties to the vehicle manufacturers, because they coincide with the requirement of reducing toxic emissions of hydrocarbons (the second phase for the Californian gasoline reformulation was introduced in 1996). They are also linked with the rising expectations for the durability of the emission limiting systems after 50000 to 120000 miles and the need to monitor the catalytic converter condition (OBD II from 1994). There will be more stringent requirements for the evaporative emission (device durability - 15 years or 150000 miles).

In 1998 CARB approved the proposal for the LEV II legislation, for the years 2004-2010. According to the accepted standards, by 2007 the emission level for the vehicles currently falling into the LDT and MDV categories- GVW below $8500 \mathrm{lbs}$ (mini vans, pickup trucks, trucks and sport utility vehicles) must be the same as for the PC vehicles. These regulations standardize norms for limiting the emissions by the PI and CI engines. Additionally, according to what was agreed, the standard will entail:

- lowering the limit for the $\mathrm{NO}_{\mathrm{x}}$ emission by $75 \%$,

- lowering the PM emission for LDV,

- the necessity to meet the emission standards after 120000 miles,

- further reduction of the evaporative emission limits,

In the case of EZEV vehicles (Equivalent Zero Emission Vehicle) the total emission will be a sum of the emissions from the FTP75 test and evaporative emission test.

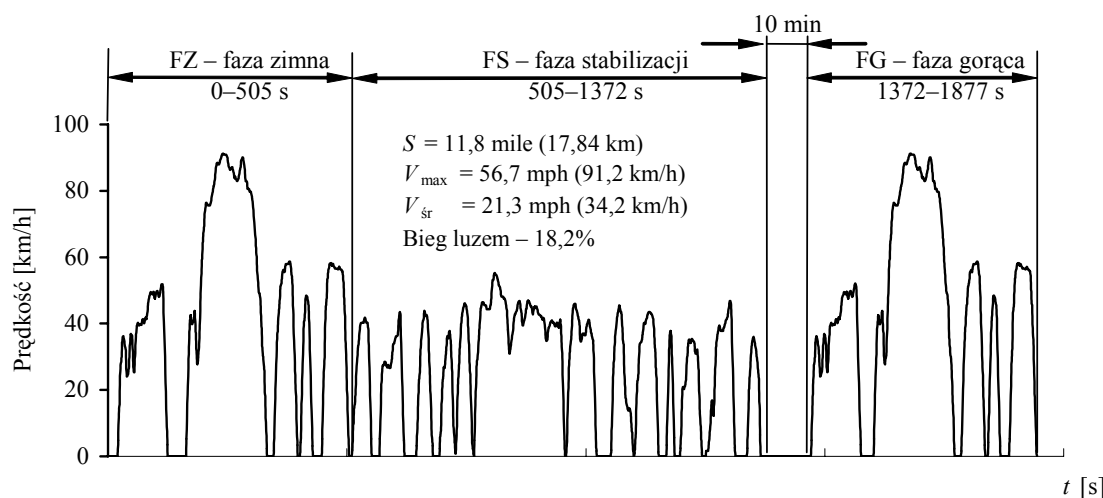

Figure 2: $\quad$ American federal test procedure (US EPA FTP 75) [1].

\section{National regulations and testing methods}

The Diagram of obligatory vehicle inspection in Poland is presented in Fig. 3.

Vehicles put in use are divided into two groups:

- subject to type approval,

- not subject to type approval. 
According to the "Road traffic Regulations" a complete vehicle type approval certificate is issued based on the results of the tests relying on verification whether a given vehicle type complies with certain conditions determined in the UN-ECE Regulations accepted by Poland, together with the obligatory amendments since the date of their issue. In August 1992 the Council of Ministers in Poland passed a resolution on accepting the package of UN-ECE Regulations, including all obligatory emission regulations - such as Regulation 83. They became obligatory for the vehicle type approval on 13.11.1992. The domestic requirements on toxic emissions originate from the requirements of Regulation 83.

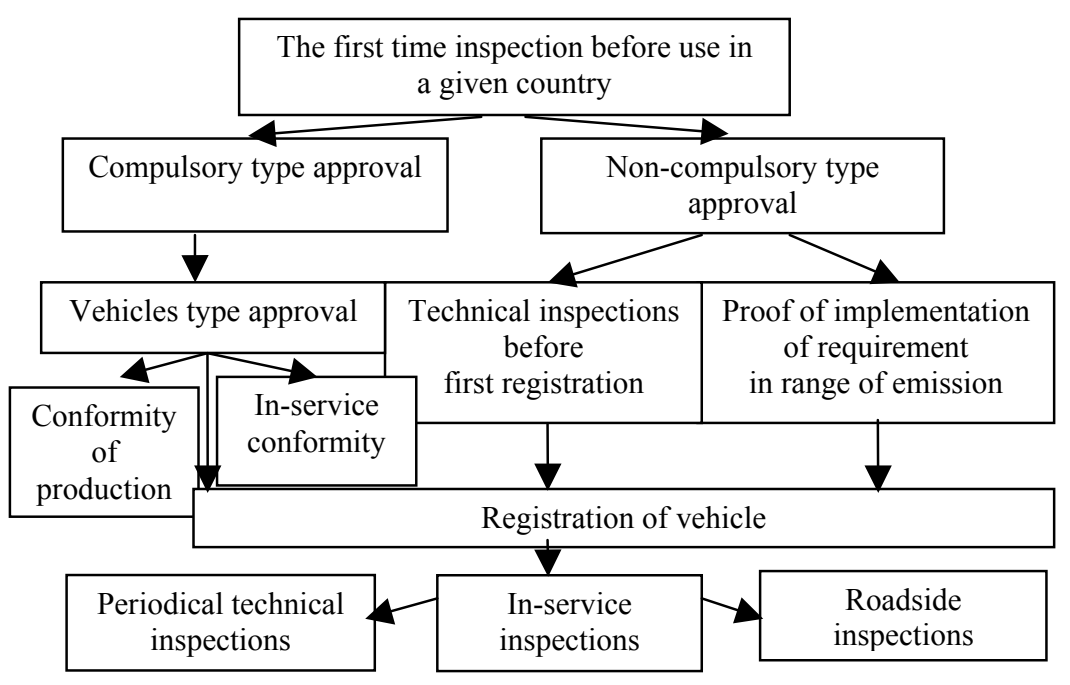

Figure 3: Diagram of vehicle inspection system in Poland [3].

Domestic regulations for the vehicles in use introduce:

1) for the vehicles fitted with PI engines:

- measurement during engine operation at idle speed: maximum carbon monoxide content at idle should not exceed $0.3 \%$ vol. of $\mathrm{CO}$, and hydrocarbons $-100 \mathrm{ppm}$, as opposed to motorcycle tests $-4.5 \%$ vol. of $\mathrm{CO}$,

- measurement during engine operation at high idle speed: carbon monoxide content should not exceed $0.2 \%$ vol. of CO, and hydrocarbons $-100 \mathrm{ppm}$, Lambda should oscillate around $1 \pm 0.03$. This does not concern motorcycles.

2) for the vehicles fitted with CI engine: smokiness of the exhaust gases measured during free engine acceleration, in the range from idle speed to maximum rpm, can not exceed values listed below:

- $2.5 \mathrm{~m}^{-1}$ for all vehicles, except those fitted with turbocharged engines,

- $\quad 3.0 \mathrm{~m}^{-1}$ for the vehicles fitted with turbocharged engines,

- $1.5 \mathrm{~m}^{-1}$ after 30 June 2008 . 


\section{Remote sensing examinations under real traffic conditions}

In the United States it has been observed that the remote sensing tests, which consist in indirect evaluation of the exhaust toxicity, are being increasingly used. Measurements are taken on separate stands for trucks and passenger cars. The test consists in measuring toxic components using NDIR type analyzers (placed at the height of the exhaust pipe outlet: for passenger vehicles - about $30 \mathrm{~cm}$ above the road, for trucks - they are placed at the height of 3-3.5 m) while the vehicles move with the speed of about $40 \mathrm{~km} / \mathrm{h}$. The results of the toxicity tests are communicated with an appropriate color light (green - serviceable, red toxicity limit exceeded) upon leaving the test section.

\section{Road testing (on-vehicle) under real traffic conditions}

The road tests, in real traffic conditions are most desirable because only then is it possible to obtain information about vehicle real emissions [7].

Portable measurement systems for testing toxic components in the exhaust gases from vehicles in real traffic conditions, PEMS in short (Portable Emissions Measurement Systems) enables measurement of the exhaust gas toxic components both in laboratory and road conditions from vehicles fuelled with gasoline, diesel, LPG, CNG and those powered by hybrid systems. The available sets ensure simultaneous measurement of at least the following: $\mathrm{CO}, \mathrm{CO}_{2}, \mathrm{THC}$, $\mathrm{NO}, \mathrm{NO}_{2}$ (if necessary $\mathrm{NO}_{\mathrm{x}}$ ). The sets enable work at the ambient temperature of 0 to $45^{\circ} \mathrm{C}$, relative humidity up to $80 \%$ and at the elevation above the sea level of up to $1500 \mathrm{~m}$. These devices are fitted with tanks (with regulators) filled with operating gases (working and calibration).

The tests are conducted on the portions of several dozens to several hundreds of kilometers in varying road conditions (fig. 4). At present the biggest inconvenience of such a test is the cost of the measuring equipment. The benefit is that the tests results are reliable and impossible to obtain under the simulation conditions on a chassis dynamometer. Such tests are conducted at present in the USA (in Poland as well) in order to compare the measurement capabilities for a variety of cars using this type of equipment that incorporates analyzers: NDIR $\left(\mathrm{CO}_{2}\right)$, HFID (THC), CLA or NDUV $\left(\mathrm{NO}_{\mathrm{x}}\right)$ or that enables the PM measurement (for example Micro Soot Sensor \& Conditioning Unit). The obtained results confirm a very high changeability of the emission level from the vehicles because the total margin of the measured values falls in the following range: for $\mathrm{NO}_{\mathrm{x}}-700: 1$, for $\mathrm{HC}-10: 1$, for $\mathrm{CO}-1000: 1$ and for fuel consumption $-4: 1$.

Using PEMS for the needs of the inspection stations seems feasible e.g. for the tests of NEDC, FTP 75, IM 240, US06 etc. at the station or on the road. It will be necessary to set the appropriate limits. In the USA PEMS instruments comply with the new regulations, including part 1065; sub-part "J". Fig. 5, 6, 7 presents a comparison of the emissions of selected exhaust gas toxic components for various types of tests using PEMS and analytic equipment of the chassis dynamometer. 


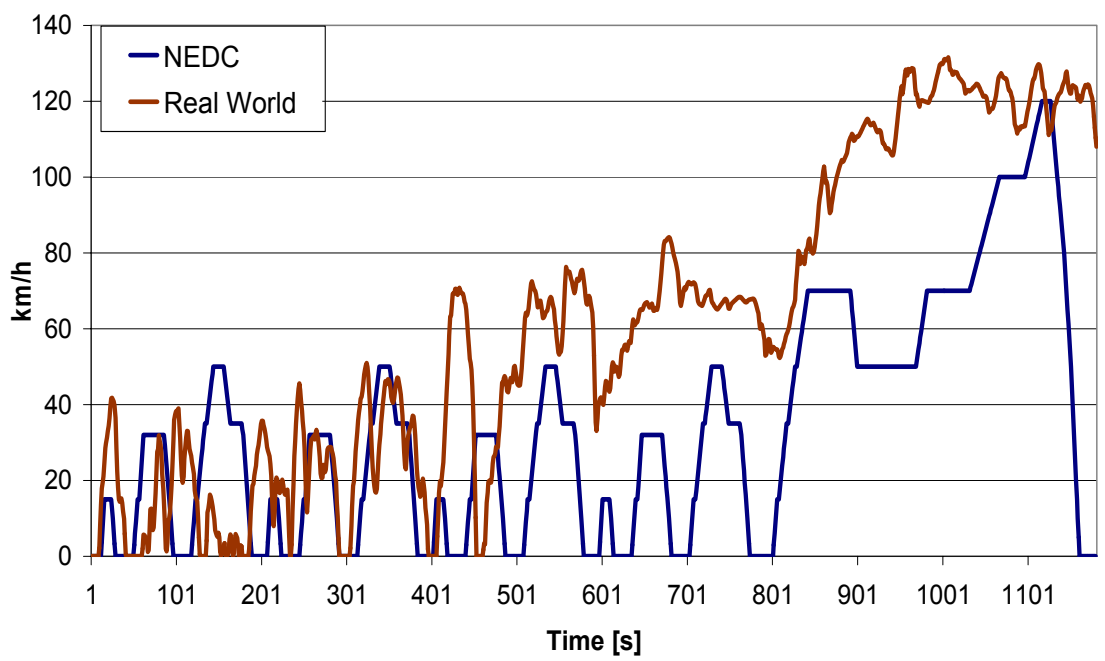

Figure 4: $\quad$ Course of vehicle speed under real conditions of road traffic and in NEDC test [6].

NOx - US06

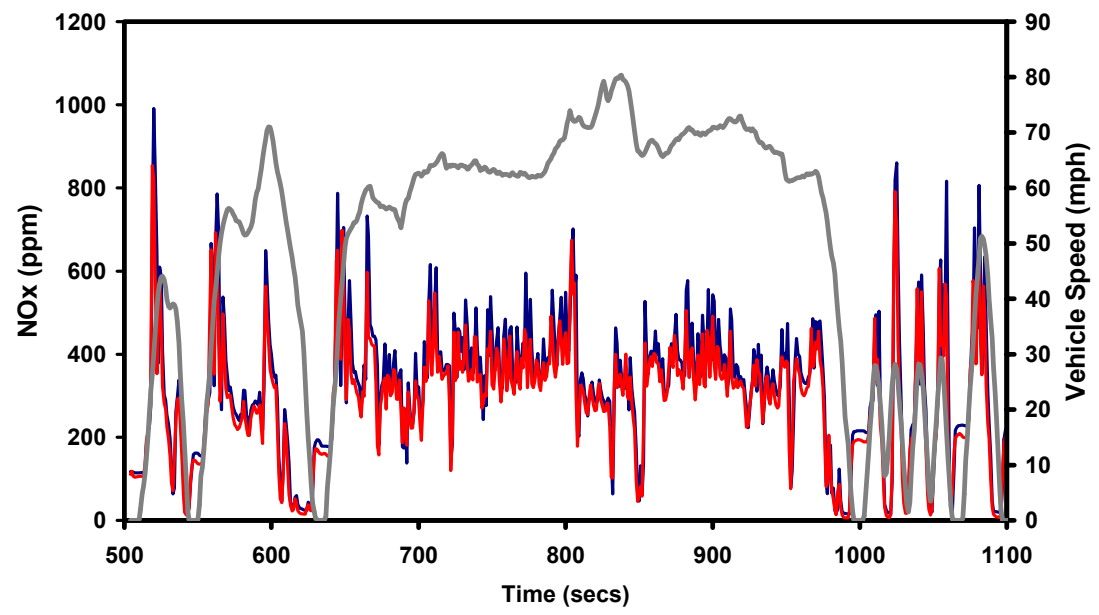

-SEMTECH-D — Horiba - Vehicle Speed

Figure 5: Course of $\mathrm{NO}_{\mathrm{x}}$ concentration (ppm) in time during a test on a chassis dynamometer while portable measurement system and analytical equipment of chassis dynamometer are used (test US06) [9]. 
THC Emissions Comparison Data - 505

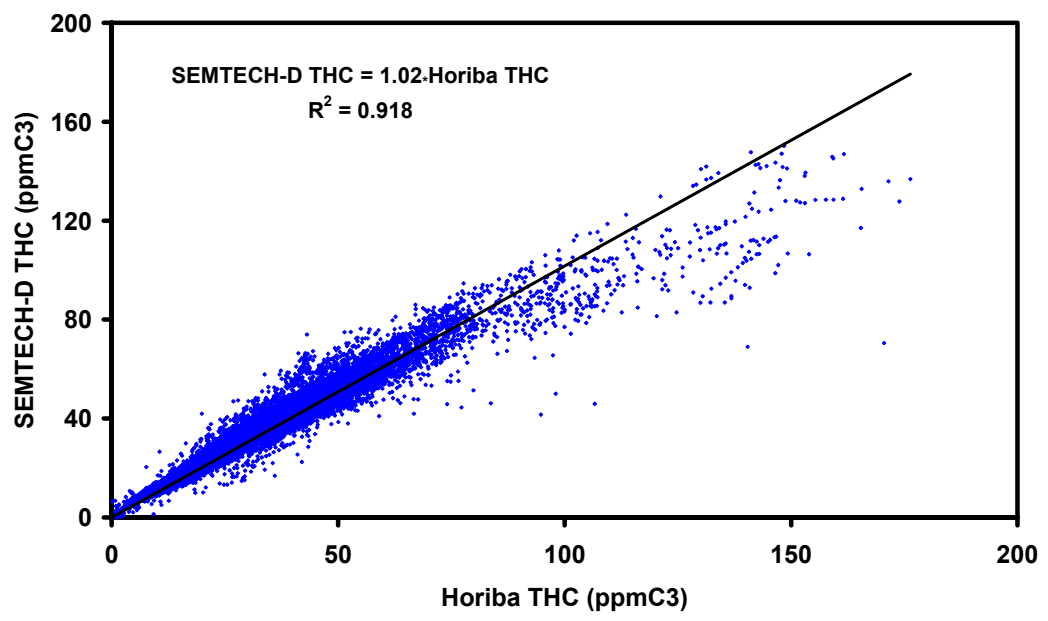

Figure 6: $\quad$ THC emissions comparison data during FTP 75 test on a chassis dynamometer while portable measurement system and analytical equipment of chassis dynamometer are used [9].

Przebieg stężeń NOx

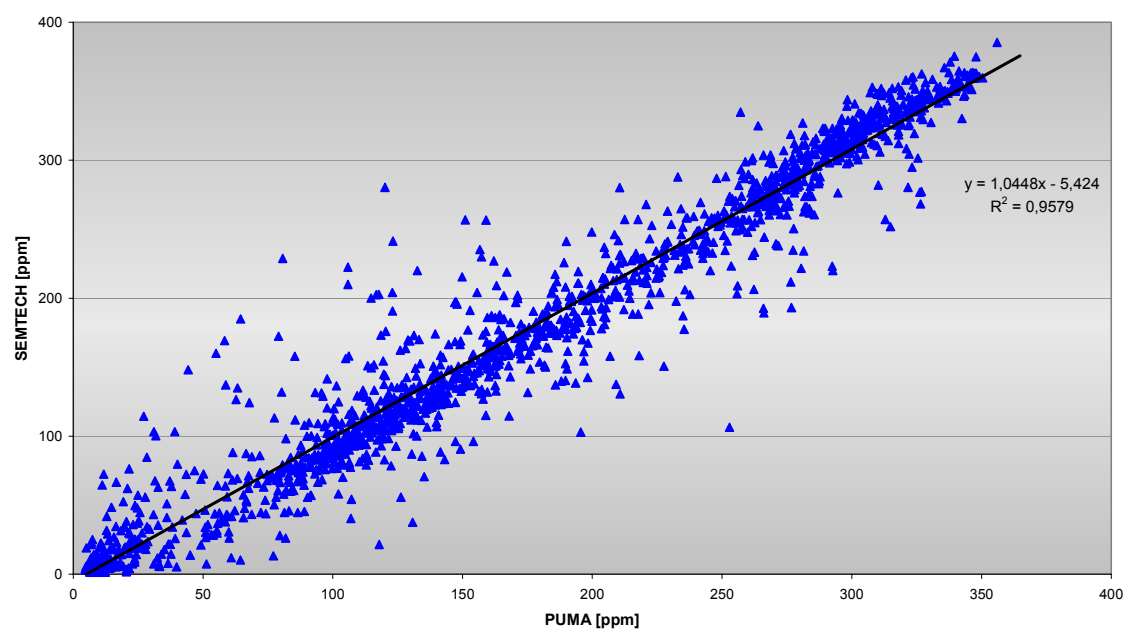

Figure 7: $\quad \mathrm{NO}_{\mathrm{X}}$ emissions comparison data during ETC test on engine test bed while portable measurement system and analytical equipment of engine test bed are used [own data]. 
Portable measuring sets can also be used for measuring exhaust toxic substances emission from different vehicle categories i.e. tractors or other machines such as ships, aircraft or engines for non-road applications (construction, agricultural machinery etc.). Mobile emission measurement is a new approach in the evaluation of the exhaust toxic component emission from the vehicles and is decidedly cheaper than measurements carried out on the test beds.

\section{A concept for vehicle technical inspections in Poland}

Taking advantage of the experience of other countries, which use the OBD system information in the technical tests, the inspection procedures in Poland should go as follows (Fig. 8) [8]:

1. Filler cap tightness test - test simulation in the SHED test, type IV tests in the type approval procedures (lack of positive result of such test disqualifies the vehicle for further test algorithms, repair and a repeated inspection are required);

2. Idle test - equivalent to the test type II in the type approval tests algorithm (admissible CO concentration level is $0.5 \%$ vol.);

3. Simplified test on the chassis dynamometers - simulation of the test type I (NEDC cycle) in the type approval tests (within the admissible emission level of the toxic substances, the warm phase of the engine should be taken into consideration - contrary to the type approval test, which begins from a cold engine start) [option -test with the use of PEMS];

4. OBD test - equivalent to a test type VII in the type approval test algorithm. Meeting the following conditions renders the test positive: serviceability of MIL indicator, lack of registered error codes and realization of all monitors.

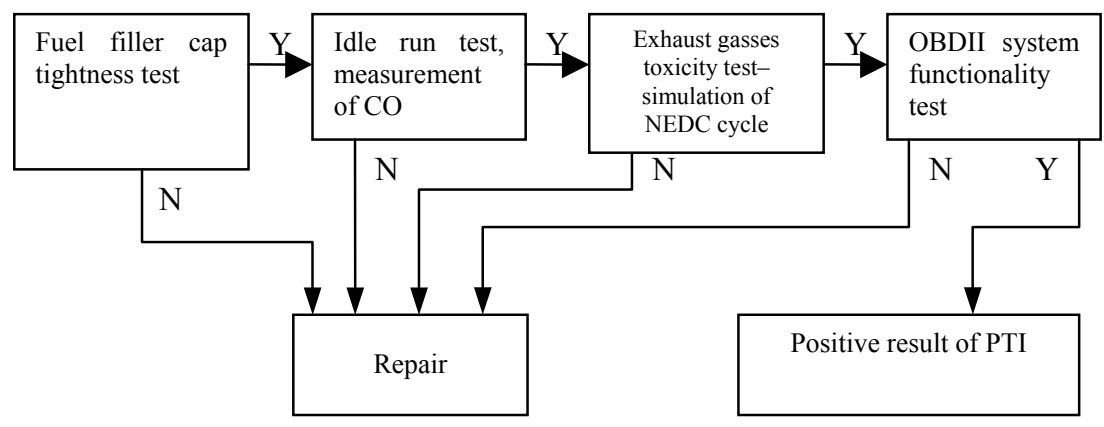

Figure 8: Algorithm of a technical inspection (authors' version).

Based on the presented description of the vehicle test procedures - the best and the most reliable is the road test under real traffic conditions. These tests, although showing certain discrepancies, are reliable - reflecting real level of the vehicles emission. 
Remote sensing tests are less precise and carried out with the use of NDIR type analyzers are characterized by different test procedures for trucks and passenger cars.

Based on the periodical tests of vehicles conducted in Europe, in comparison to the previous methods, less emission information is obtained; lack of the road test and engine loads do not allow obtaining the information on the vehicle emission, but only the concentration of the components at the increased engine speed. Periodical tests in the USA conducted on the chassis dynamometers in the drive test provide more information about the vehicle technical condition, at the same time showing technological advancement of those emission testing centers.

\section{References}

[1] AVL: Current and Future Exhaust Emission Legislation. AVL List GmbH, Graz 2005.

[2] Merkisz, J.: Badania emisji pojazdów w eksploatacji, Seminarium SIMR, Warszawa 2005

[3] Merkisz, J., Gis W.: Stan obecny (na rok 2004) i kierunki zmian przepisów toksyczności spalin z silników spalinowych, V Konferencja szkoleniowa: Badania Techniczne Pojazdów w Świetle Obowiązujących Przepisów, Mikołajki 20-22 października 2004, s. 91-104.

[4] Neville T.: Advanced Conventional Fuels, Materiały konferencji: Future Worldwide Emissions Requirements for Passenger Cars and Light Duty Vehicles and Euro V, Milan 11.12.2003.

[5] Processing CITA Conference „Global Perspective on Roadworthiness Enforcement", organized by International Motor Vehicle Inspection Committee. Chicago 24-28.05.2005.

[6] Singer, W., Noest, M., Libing, X.: In-Vehicle Emissions Tester CATARC Seminar, Beijing, May 2005

[7] Spears, M.: On-Vehicle Emissions Measurement and Test Procedures; Materiały konferencji: Future Worldwide Emissions Requirements for Passenger Cars and Light Duty Vehicles and Euro V, Milan 11.12.2003.

[8] Merkisz, J., Gis, W.: Metody badań emisji substancji toksycznych spalin z pojazdów w rzeczywistych warunkach ruchu drogowego. X Konferencja Naukowo-Techniczna n.t. Innowacje w motoryzacji a ochrona środowiska. Słupsk 2007r.

[9] Gierczak, CH., A., Korniski, TH. J., Wallington T. J., Butler, J. W., Ensfield, C.: Inter-Comparison of the SEMTECH-D PEMS and Conventional Laboratory Dynamometer Instrumentation for the Analysis of Medium Duty Diesel Exhaust. Milan, Italy 2007. 